\title{
Post Succession Performance of Medium Size Family Owned Business in Sri Lanka
}

\author{
A.C. De Alwis \\ Department of Human Resource Management, Faculty of Commerce and Management \\ Studies, University of Kelaniya, Sri Lanka \\ dealwisac@gmail.com / chamaru@kln.ac.lk
}

\begin{abstract}
Post succession performance of family owned businesses has become ineffective. Literature specifies that inter-generational succession is the prime cause for succession failures. In this setting, current family owned businesses focus attention on finding alternative, profitable succession modes. The foremost purpose of this research was to compare performances of family and non-family successors. The target population was selected were the successors of family owned businesses. The criteria to select the population were the family owned businesses that contain between 50 and 149 employees and who were involved in a business succession process within the last 10 years excluding the three years, 2007 to 2010. Sample units were selected through simple random sampling method and consist of 128 units. The main data collection modes were a structured research questionnaire mail-out, and also in-depth discussions held with successors. According to study findings, not all successors were satisfied with the business succession process. Unrelated manager successors have higher satisfaction then the family member successors, but neither group exceeds the moderate level. This study found that if successors were not satisfied with the business succession process, it badly affected their following business performance. All successors lowered business performance efficiency and recorded worse performance than the incumbent. However unrelated manager successors recorded better results than the family member successor in both categories. Therefore, if family members are not available or prepared for business succession, unrelated manager are a good alternative.
\end{abstract}

Keywords: Post succession performance, Medium sized businesses

\section{Background of the Study}

According to O'Hare (2003) "Before multinational corporations, there was family business; before the Industrial Revolution, there was family business; before the enlightenment of Greece and Empire of the Rome, there was family business". This statement accurately outlines the history of this exceptional type of worldwide business 
unit. Family-Owned Businesses (FOBs) dominate the current world economy in particular eras in the past but also at present (Morck and Yeung, 2004). The current degree of business performance, though, is somewhat different. Current FOBs have problems sustaining their business. The reality is of course that FOBs are currently struggling in the worldwide crisis, with their problem of inheriting their business. In other words, they are struggling for long-term survival after a new Chief Executive Officer (CEO) succeeded the business (Chung and Liu, 2007).

In recent history, FOBs have increasingly been considered concerning policy decisions (Mandl, 2008), because they greatly contribute to economic and social development (Mandl, 2008). FOBs are actually the predominant form of business organization, and play a vital role in today's Capitalistic economy and social well-being. Beckhard and Dyer (1983) estimated the number of FOBs worldwide, and confirm that about $65 \%$ to $90 \%$ of all businesses in various nations continue to develop this sector. According to Malhotra (2010), $80 \%$ of all businesses worldwide are family businesses. In Europe, more than $75 \%$ of all businesses are family owned. They contribute greatly to Gross National Production (GDP) in most nations and are quite proudly the main employment provider.

Because of these conditions, FOBs have become the dominant sector in the Capitalistic economy. In other words, if FOBs perform well, they stimulate the economy, increase GDP and decrease the level of unemployment (Sharma, 1997; Venter, Boshoof and Mass, 2005). Likewise, if FOBs perform poorly, they badly affect the national economy, decrease GDP and increase the level of unemployment. The social cost of this possible failure would contribute negatively to social and economic growth in any capitalist economy (Commission, 2006).

According to research findings, FOBs give foremost preference to hand over the business to family members because their ambition is to preserve family company ownership. To achieve this, they transfer management and control to the next generation (Morris, Williams, Allen and Avila., 1997; Lansberg, 1999), without considering the level of competence of the successor. The leading argument for this generational succession is the belief that family members can gather social capital, resources and specific knowledge on running the firm in a more efficient and profitable manner (Bjuggren and Sund, 2001). 
According to Davis, Schoorman and Donaldson (1997) "the family successor could perform better than other managers because they are exposed to higher non-monetary rewards associated with the firms' success that other successors do not share." They further argue "to get solid, specific knowledge and high levels of trust from key stakeholders is very difficult to outsiders."

However, FOBs face one extremely vital issue with their generational business succession. According to Ward (1987); Davis and Harveston (1998); and Kets de Vries (1993) "only $30 \%$ of FOBs survive into the second generation, and $15 \%$ survive into the third generation." Miller, Steier and Breton-Miner (2003) explain that poor Business Succession Process (BSP) is the central reason for this. This scenario has not only affected particular organizations, but has also directly affected the national economy due to lack of contribution.

Regarding the American Family Business Survey (1997) (citied in Sharma, et al., 2003a) BSPs define as "the transfer of leadership, ownership or control from one family member to another - a goal shared by a majority of family firms" and as "a transfer the leadership one family member to another."

Conducting the business as a FOB, "each generation takes over the business from the previous generation, and this is the vital managerial challenge for the incumbent, owners, successors and family members" (Miller et al., 2003), but they have failed to do this in a successful manner. BSPs have gone beyond that stage by considering alternative succession modes, not for family control but for the survival of the organization as a FOB. Nelton (1997) expressed that "families are now starting to recognize that it is not the end of the family enterprise if you bring in a non-family executive to lead the firm". In other words, at present there is a trend to be a FOB as a "family owned - non-family managed" model, not as a "family owned -family managed" model. Therefore, the business succession process of FOBs is better defined as "the passing of the leadership baton from the founder/owner or incumbent owner to a competent successor, who will be either a family member successor or a non-family unrelated manager successor (De Alwis, 2011)." 
Further, Lauterbach, $\mathrm{Vu}$ and Weisberg (1999), and also Smith and Amoako-Adu (1999), and Lin and $\mathrm{Hu}$ (2007), all conducted research in comparing the financial performances of family member successors and non-family unrelated manager successors in public companies to identify the most appropriate successor. Chittoor and Das (2007) discussed making management more professional with three Indian companies using case study methods. Boeker and Goodstein (1993) discussed the impact of organizational performances and the composition of the board of directors for the selection of a future successor. Those studies have contributed to the knowledge base of the field, but there is still an enormous knowledge gap to fill. No empirical research has been done on post succession performances of medium-size FOBs by comparing family member successors and unrelated manager successors.

\section{Problems of the study}

As explained previously, BSPs of FOBs have become a serious issue for the longevity of this business entity. Therefore, there is a high tendency among researchers and practitioners to find feasible solutions to this succession issue, however in FOB literature, there are very few studies comparing different succession alternatives to BSPs (Chittoor and Das, 2007; Lin and Hu, 2007). This research aims to develop an understanding of this phenomenon, identified in the previous section. Hence, the problem statements can be stated as follows:

"Who is the best performer from the family member and the unrelated managers to take over the top management position and successfully continue the business under the significant level of family involvement?"

\section{Research objectives}

The aim of this research is to identify the most appropriate succession mode without damaging the FOB identity. Therefore, the objectives are:

i. To compare family member successors with unrelated manager successors based on the successors' initial satisfaction with the business succession process and also post succession business performance. 
ii. To evaluate the relationship between initial satisfaction with the business succession processes and post succession business performance.

\section{Significance of the Research}

There is a bulk of literature on various issues relevant to FOBs, but the majority of this is focused on inter-generational succession (Handler, 1994 and Wortman, 1994). This is due to poor performance the BSP brings short-term life to the entire unit (Handler, 1994). This poor result affects the business entity and eventually also the national economy. Therefore, business succession processes have become a fundamental topic of FOB research (Sharma, et al., 1996).

Almost $99 \%$ of the literature on FOB succession deals with inter-generational succession, and very few researchers have given their attention to alternative succession modes (Lauterbach et al., 1999; Smith and Amoako-Adu, 1999; Boeker and Goodstein, 1993; Chittoor and Das, 2007; Lin and Hu, 2007). However no one has analyzed business performance after succession with the aim of comparing different succession models, especially in medium-sized FOBs.

\section{Exploratory Study}

This study only discusses management succession, and it does not discuss ownership succession, though often both happen simultaneously. Top management succession is a particularly challenging event for any type of business organization because the successor's approach, competencies and perception directly affect all aspects of the business, and also stakeholder's expectations. The American Family Business Survey (1997) defines BSPs of FOBs as "the transfer of leadership, ownership or control from one family member to another - a goal shared by a majority of family firms." Meijaard, Uhlaner, Flören, Diephuis and Sanders (2005) goes beyond this to define BSPs of FOBs as "...a transfer to someone within the family, to a third party, or to another company". Management buy-ins (MBI) and management buy-outs (MBO) can be considered examples of business transfers as well, as long as the existing economic entity survives." According to Beckhard and Burke (1983) (cited in Handler, 1994) BSPs are "the passing of the leadership baton from the founder-owner to a successor who will either be a family member or a non-family member; a 'professional manager." 
For FOBs, family members are interested in transferring management into another family member's hand, mostly transferring to the next generation's hand. This is because their intent is to preserve company ownership and management within the family. They transfer management and control into the hands of the next generation (Morris et al., 1997) without considering the competence level of the successor. The leading justification for this inter-generational succession is the belief that family members are able to accumulate social capital, resources and learn specific knowledge on running the firm in a more efficient and profitable manner (Bjuggren and Sund, 2001).

According to Davis et al. (1997), family successors might perform better than unrelated managers, because they have developed better non-monetary rewards which helps guarantee the firms' success. Additionally, Donnelley (1964), (cited in Alestalo, 2010), argues that "to get firm specific knowledge and higher levels of trust of key stakeholders is very hard for outsiders." According to previous research findings, only a limited number of FOBs survive to the second generation and more than two-thirds do not pass to the third generation (Shanker et al., 1996). Kets de Vries (1993) writes that only "30\% of FOBs survive into the second generation, and 15\% survive into the third generation". Poor successions are the main reason businesses fail to continue (Miller and Breton-Miner, 2003). Other causes are implementing incomplete and vague succession plans, selecting incompetent or unprepared successors, and also family conflicts (Dyer, 1986; Handler, 1990, 1992; Lansberg, 1999; and Morris et al., 1997). Due to this, there is a current trend to operate as a "family owned and non-family managed" business instead of the "family owned and family-managed" business.

Therefore BSPs of FOBs can be better defined as the "transition of leadership from the founder - owner or incumbent-owner to a competent successor. The successor might be a family relative or non-family manager."

\section{Business Succession and Performance}

An extensive search was done to find available literature on BSPs and its affect to post succession performance, but very few contributions were found. In total, 9 articles were reviewed, but the majority of them do not relate to the FOBs. Some compared FOB performance to non-FOBs. A few studies researched the relationship between performance 
before succession and its impact on selecting an appropriate succession mode, and other researchers evaluated the post succession performance with succession modes. The majority of research was conducted in the United States, Canada, the United Kingdom and Australia, and only 2 theses conducted research in the Asian region.

\section{Table 1: Business Succession and Performance}

\section{Author \\ Objective \\ Key findings}

\begin{tabular}{|c|c|c|}
\hline $\begin{array}{l}\text { Amran and } \\
\text { Ahmad ( 2010) }\end{array}$ & $\begin{array}{l}\text { Examine the relationship } \\
\text { between family } \\
\text { successors' attributes and } \\
\text { firm performance. }\end{array}$ & $\begin{array}{l}\text { Founder-manager firms } \\
\text { recorded worse performance } \\
\text { than successor-manager firms. }\end{array}$ \\
\hline $\begin{array}{l}\text { Daily and } \\
\text { Dollinger (1992) }\end{array}$ & $\begin{array}{l}\text { Compare family owned } \\
\text { and managed with } \\
\text { professionally managed } \\
\text { firms. }\end{array}$ & $\begin{array}{l}\text { There are significant } \\
\text { differences between FOB and } \\
\text { non - FOB performances. }\end{array}$ \\
\hline King (2003) & $\begin{array}{l}\text { Evaluated performance } \\
\text { after succession is } \\
\text { attributed to differences } \\
\text { in predecessors. }\end{array}$ & $\begin{array}{l}\text { Successor's potential } \\
\text { capability, commitment and } \\
\text { skills bring positive results and } \\
\text { better performance }\end{array}$ \\
\hline Kotey (2005) & $\begin{array}{l}\text { Examine the differences } \\
\text { between family and non- } \\
\text { family SMEs and their } \\
\text { performances. }\end{array}$ & $\begin{array}{l}\text { Small and medium-sized family } \\
\text { firms perform better than non- } \\
\text { family small and medium-size } \\
\text { firms. }\end{array}$ \\
\hline $\begin{array}{l}\text { Lauterbach et al. } \\
\text { (1999) }\end{array}$ & $\begin{array}{l}\text { Identify the factors } \\
\text { influencing successions, } \\
\text { and measure post } \\
\text { succession performance. }\end{array}$ & $\begin{array}{l}\text { There is a relationship between } \\
\text { successor selection and firm's } \\
\text { performance. } \\
\text { Weak performing companies } \\
\text { give priority to appoint non- } \\
\text { family successors. }\end{array}$ \\
\hline $\begin{array}{l}\text { Lin and } \mathrm{Hu} \\
\text { (2007) }\end{array}$ & $\begin{array}{l}\text { Give background to } \\
\text { family firms and their } \\
\text { successor selected, and } \\
\text { investigate the } \\
\text { performance of CEOs } \\
\text { from different } \\
\text { backgrounds. }\end{array}$ & $\begin{array}{l}\text { When a family member is a } \\
\text { successor, it brings better } \\
\text { performance. }\end{array}$ \\
\hline
\end{tabular}




\begin{tabular}{lll}
\hline \multicolumn{1}{c}{ Author } & \multicolumn{1}{c}{ Objective } & \multicolumn{1}{c}{ Key findings } \\
\hline González (2001) & $\begin{array}{l}\text { Examine the impact of } \\
\text { family control on the } \\
\text { firms' performance }\end{array}$ & $\begin{array}{l}\text { When the successor is a family } \\
\text { member, it brings better } \\
\text { performance than unrelated } \\
\text { successors. }\end{array}$ \\
\hline $\begin{array}{ll}\text { Smith and } \\
\text { Amoako-Adu }\end{array}$ & $\begin{array}{l}\text { Management successions } \\
\text { immediate and long-term } \\
\text { affects in financial } \\
\text { performance within the } \\
\text { Canadian family }\end{array}$ & $\begin{array}{l}\text { There is no significant } \\
\text { difference between non-family } \\
\text { insider successors and non- } \\
\text { family outsider successors. }\end{array}$ \\
& controlled firms & \\
\hline
\end{tabular}

Source: Past Researches shown above

\section{Succession and Post-performance}

There is no clear agreement among researchers on how to measure a successful or effective succession (Dyer, 1986; Handler, 1989a; Morris et al., 1997; and Cabrera-Suárez et al., 2001). Handler (1989a) and Sharma (1997), explain whether it is suitable to use the satisfaction level of the incumbent, the successor, and other family members as an indicator of whether the BSP is perceived to be successful. Sharma et al. (2001) express this as a "subjective assessment of an individual about the process and decision regarding the selection of a new top manager, based on perceptions rather than objective criteria."

Handler (1989a) and Morris et al (1997) discuss the differences of the BSP experience from two perspectives. That is, how family members personally experience the succession process (subjective assessment), and the effectiveness of the BSP (more objective assessments of the outcome of the transition). Harvey and Evans (1995) and Handler (1989b) along with Goldberg (1996), point out that stakeholder satisfaction with the BSP indicates not only a successful BSP, but also the successor's ability to keep the family business healthy by sustaining growth and continuing to be profitable. Sharma et al. (2001) express business performance as a criterion to show the BSP was effective. It has become an evaluation criterion to determine whether the CEO will survive (Sharma et al., 2001).

Evaluating those situations, Venter et al. (2005) summarize it as follows: 
"... in order to ensure the success of the succession process, all the different stakeholders involved in the process (the predecessor, successor, family, network, suppliers, etc.) must be satisfied with its outcomes, and the successor should have the ability to ensure the sustainability and financial security of the family business after the succession process has been completed."

Two-dimensional evaluation of the BSP, address to the uniqueness of the FOBs, (because it has subjective and objective indicators). Professionally managed business ownership is widely dispersed, and they usually employ business performance to measure success (Pitcher, Chreim, and Kisfalvi, 2000; Venter et al., 2005). However, maintaining good family relations is also an extremely important evaluation criterion (Venter et al., 2005) and in some instances, family members give priority to other members' personal satisfaction instead of business profitability (File, Prince, and Rankin., 1994; Tagiuri and Davis, 1992).

Sharma et al. (2001) explain and expand the argument between these two opposing dimensions of success in management succession. According to them...

"Dissatisfaction with the succession process could cause interminable conflicts that make the succession ineffective. On the other hand, if the succession is not effective, dissatisfaction with the succession process, after the fact, could occur. In summary, studying satisfaction with the succession process is important because of its direct impact on the relationships among family members, an important consideration in many family firms, and because of its impact on effectiveness. "

Further they suggest that:

"The relationship between satisfaction and effectiveness is likely to be intertemporal in nature (Sharma et al., 2001)."

The initial satisfaction with the business succession process generally encourages better performance and usually brings booming post succession business performance, and this excellent post succession performance brings FOBs some personal satisfaction. Likewise, if stakeholders are not satisfied with the BSP, this discourages them from performing their 
roles as well as possible in the proper manner, and this will affect post succession performance both directly and indirectly. This finally brings dissatisfaction to the whole business process. Post succession performance has a direct affect on the FOB and directly influences the level of satisfaction and hunger for the business unit to survive (CabreraSuarez et al., 2001; Dyer, 1986; Handler, 1990 and Sharma et al., 2001).

\section{Research Design}

There is no definite agreement among researchers about what contributes to the successfulness or effectiveness of BSP in FOB. Some researchers suggest "satisfaction of the BSP from the incumbent, the successor and other family members, as the indicator of the perceived success" (Cabrera-Suárez et al., 2001; Dyer, 1986). However, those researchers have considered only one side of the BSP, which is the main stakeholders' (the incumbent, the successor and other family members') satisfaction with the BSP. Apart from that, others have used "successors' ability to keep the FOB healthy" as the measurement to appraise the business unit. Venter et al. (2005) and Sharma and Irving (2005) express the perceived success of the BSP is determined by the extent of satisfaction with the process and continued profitability. Handler (1989a) and Morris et al. (1997) also mention that "success has two interactive dimensions: satisfaction with the process and the effectiveness of succession." Chrisman et al. (2005) express the importance of family relations and the effectiveness of the business entity, and they identified two perspectives to measure the success of the process: business performance and family harmony, and named these as "two pillars for family firm performance." The author agrees with CabreraSuarez et al. (2001) ; Dyer (1986); Handler (1990); Morris et al. (1997); Sharma et al. (2001) and they believe that the success of the BSP is defined as "the subsequent positive performance of the firm, the ultimate viability of the business and the satisfaction of stakeholders with the succession process." At last, a conceptual argument can be brought toward as an interactive relationship between these two dimensions of success in the BSP of FOB. According to Sharma et al. (2001) “...performance may also alter family member's satisfaction with the succession process even in the absence of any changes in the relationships among family members." 


\section{Operationalization of Variables}

This study includes both subjective and objective measures to evaluate FOB performance. It was measured subjectively by the initial satisfaction with the business succession process, and it has measured business performance objectively and subjectively.

\subsection{Initial satisfaction with the business succession process}

Cabrera-suárez et al. (2001) and Dyer (1986) suggested using the satisfaction of the incumbent, the successor and other family members with BSP as an indication of the perceived success of the BSP. Sharma et al. (2003a) employed this performance indicator for their research on "predictors of satisfaction with the succession process in family firms." Sharma et al. (2001) collected data to measure satisfaction from incumbents and successors, but no data was collected from family members due to the limitation of the research framework. Their sample framework was FOBs that expected succession within the ensuing five years, and also those for which the event had occurred within the preceding five years. Under this research framework however, this study has collected data from FOBs who had their BSP within the period from 2000 to 2007. Therefore, it has failed to collect data from incumbents and their family members. Therefore, this study has come to the decision to measure initial satisfaction with the business succession process of the successors of various business units. This study defines initial satisfaction with the business succession process as "perceived satisfaction of succession before post succession FOB performance is accurately known."

\subsection{Post succession business performance}

This study used business performance as the second dependent variable. Business performance has several related terms such as business development, and business improvement. Riding (2005) illustrates that business performance can be divided into four categories: financial performance, customer base performance, employee base performance and environmental base performance. Jarvis, Kitching, Curran and Lightfoot (1996) have revealed in their organizational theories and accounting literature, that profit maximization is the central goal of firms. In that way, some studies have included both 
objective measures, which are obtained from organizational records (Seashore and Yuchtman, 1967) and subjective measures, which are perceptions collected from organizational members and stakeholders (Campbell, 1977).

In order to be objective, this study considered financial performance the same as business performance. Furthermore, Zahra (1991) emphasises that growth measures for performance may be more accurate and available than accounting measures of financial performance. Rosemond (n.d) (cited in Etzioni, 1964) has reported that performance should be viewed in relation to one or more goals in an organization, and has suggested percentages to measure performances for businesses. In this context, this author agrees that business performance is a valid indicator for assessing the effectiveness of BSP (Morris et al., 1997; and Goldberg, 1996). Hence, this has been used to compare pre and post succession performances of FOBs.

In various literature, relatively few papers endeavour to address this issue empirically, but most attempts focus on the comparison between family and non-family businesses (Daily and Dollinger, 1992 as cited in Wang., Watkins, Harris, Spicer, 2004) instead of the different modes of successes. Academics and researchers argue that business performance is a multi-dimensional construct (Fitzgerald and Moon, 1996 as cited in Wang et al., 2004). There are two highly recognise business performance modes for the evaluations named: the European Foundation Quality Management model and the American Malcolm Baldrige National Quality Award model. These provide a comprehensive framework that assesses companies directly and compares them with others. However, these two models are only highly appropriate for large-size companies and not medium and small sized organizations (Wang et al., 2004).

Financial outcomes enable managers and business owners to make decisions and plan business development (Jenkins, 1995 as cited in Wang et al., 2004). Financial outcomes are broadly utilized in the SME and entrepreneurship literature (Morris et al., 1997). However, there is broad agreement that no one single financial indicator can accurately and comprehensively capture business performance, particularly in the scope of small firms (Daily and Dollinger, 1992). Taking this into consideration, it is preferable to devise a multiple measure of financial performance and interpret the results based on one 
indicator in conjunction with other indicators. This study used business performance as a second dependent variable.

There are a number of performance evaluation tools available for profit-oriented organizations. Most of these techniques directly relate to the financial performance of the organization. "Profitability" and "management efficiency" are the indicators commonly used. Return on Equity (ROE), Return on Sales (ROS), Return on Assets (ROA) and Earnings per Share (EPS) are some common examples of profitability indicators. After considering the research population, this study expected to use Average Returns on Assets (ROA) and Average Returns on Sales (ROS).

In order to be subjective, further, this study considered to use a scale to measure successor's perception about business performance. For that, this study used scale named "the perceived success of the succession process" developed by Venter, Boshoff, and Maas in 2005 .

\subsection{Family member successors}

This research defined family member successor as "individuals who have a relationship with the incumbent and family by blood or by law. " In general, the transition will come from generation to generation, but sometimes, due to the unavailability of blood relations; there is consideration given to whether the business should be handed over to more distant, legally binding relations. Thus, this study considers both types of successors as family member successors.

\subsection{Unrelated Manager Successor}

Professionalization refers to the adoption of unrelated managers to fill management positions, especially the CEO's position (Zhang and Ma, 2009). The adoption of unrelated managers signifies the separation of ownership and control, or at least it dilutes the family control in the actual management of the business. Under these circumstances, the unrelated manager successor is defined in this research as "an individual who takes full charge of the day-to-day operations while retreating to the board of directors to assume advisory and supervising duties." 


\section{Hypothesis of the Study}

\section{Hypothesis 1: Successor and post succession performances}

This research evaluated the post succession performance of alternative succession modes. To reach this prospect, this study compared alternative succession modes with their post succession performance from two different perspectives: initial satisfaction and effectiveness.

(1) Initial satisfaction with the business succession process

Alternative hypothesis $\left(\mathrm{H}_{1 . \mathrm{a}}\right)$ : Initial satisfaction with the business succession process is significantly different with family member successors $\left(\mu_{\mathrm{SFMS}}\right)$ to unrelated manager successors ( $\left.\mu_{\text {SUMS }}\right)$

$$
H_{1}: \mu_{S F M S} \neq \mu_{S U M S}
$$

(1) Business performance after BSP

Alternative hypothesis $\left(\mathrm{H}_{1 . b}\right)$ : Post succession business performance of the two succession modes is significantly different. Performance of the family business successor $\left(\mu_{\mathrm{FMSBP}}\right)$ is significantly different to the performance of the unrelated manager $\left(\mu_{\mathrm{UMSBP}}\right)$.

$$
H_{1}: \mu_{F M S B P} \neq \mu_{U M S B P}
$$

\section{Sample Design and Data Collection}

\subsection{Population of the study}

According to Dyck et al. (2002); Handler (1989a); and Vancil (1987) (cited in Sharma et al., 2003a), "rich qualitative studies conducted on succession have all observed that the process is lengthy, and it may take 15-20 years." Therefore, identifying the exact time period of the BSP is a very hard task (Sharma et al., 2003a). To overcome this however, Sharma et al. (2003a) suggest selecting a sample from a period when involved parties can perfectly remember incidents of the BSP.

Therefore, this study screened the population of "FOBs that have done their BSP within the period from 2000 to 2007'. The study cannot include FOBs which have done their BSP after 2007 because three years of post-succession business performance is required to identify and evaluate the most suitable succession mode for FOB succession (objective 1). 
Under these circumstances, the first screening criterion assumes that the BSP was completed within the time period 2000 to 2007, and secondly it assumes that memories of the BSP are relatively fresh in the minds of the successors and that their responses will be accurate. After considering the above-mentioned situations, the research populations are shown below.

"Family owned business has done their business succession process within the period of 2000-2007 with family member successor or unrelated manager in Sri Lanka."

Due to a national database for screening being unavailable, SME database was used because according to the literature, the majority of SMEs are FOBs (Commission, 2006).

\subsection{Small and Medium Enterprises in Sri Lanka}

In Sri Lanka, SME businesses are found in different sectors such as: agriculture, mining, fishing, industry/manufacturing, construction, the wholesale and retail industry, and services in rural, urban and real estate which serve local and international markets (Dasanayaka, 2008). According to Cabraal (2007), there is no official estimation about the number of medium-size SMEs. Further, he calculated the number of medium-sized SMEs based on enterprises filing their income tax returns. According to this count, the number of medium-sized SMEs is approximately 10,000 in Sri Lanka, and represents $15 \%$ of all enterprises. SMEs account for approximately $97 \%$ of all industries in Sri Lanka (Cooray and De Silva, 2007.). SMEs are a vital sector to any capitalist economy whether it is developed or still developing. SMEs play an essential role in the Sri Lankan economy as the main GDP contributor and employment provider. Their main market is domestic but there is a notable, growing trend for SMEs to export their products.

\subsection{Sample and the Sampling Method}

Different organizations, authors and other interested parties use diverse definitions based on purpose and therefore a universally accepted definition cannot be decided. By considering the research framework, this study used the definition given by Neubauer and Lank (1998), (cited in Mustakallio, 2002) to identify the research population. According 
to them, a FOB is "any form of business association where the voting control is in the hands of a given family."

The definition of an SME has changed from country to country and even within countries. Different regions and different institutions adopt varying definitions for SMEs and some definitions include the workforce of the organization, the capital investment, turnover, or nature of the business. Sri Lanka does not have a nationally accepted definition for SMEs and different institutions adopt different definitions according to the purpose of various studies. However, the most widely accepted criteria for defining SMEs are that they have a number of employees, fixed investment, and have a certain nature of business (Cooary, 2003). In Sri Lanka, The National Development Bank (NDB), the Export Development Board (EDB), and the Industrial Development Board (IDB) all use the financial value of fixed assets as the criterion to define SMEs. The Department of Census and Statistics (DCS), the Small and Medium Enterprise Development (SMED), and the Federation of Chambers of Commerce and Industry (FDCCI) use the number of employees as the criterion (Kapurubandara and Lawson, 2006). The World Bank defines enterprise size in Sri Lanka based on the number of employees: those with fewer than 49 employees are small; those with 50 to 99 employees are medium-sized; and those with more than 100 employees are large. According to Dissanayake (2009):

“... most of these definitions are made according to organizational needs and purpose of interests about SMEs. Financial institutions, public sector authorities, non-governmental organizations (NGOs), trade and industry chambers, international organizations, researchers, SMEs service providers and consultancy firms have their own definitions based on their own criteria selection"

However those definitions are based on mainly three indicators as number of employees, capital employed/total assets and turnover. Some difficulties can be identified with these definitions, when author applies the criterion of capital employed / total assets, and turnover. This may well confuse figures due to inflation and technological improvement. Despite this, most researchers and relevant institutions use the following criteria to classify SMEs: the "value of the fixed assets" (excluding land and building), 
and the "number of employees in the enterprise" (Cooray, 2003). Due to the inflation factor, the author preferred to use only the "number of employees" for identifying FOB units for their study. According to Sumanasena (n.d)

"The most common categorization based on employees in Sri Lanka is 4 to 49 employees for small-scale enterprises, 50 to 149 for medium scale enterprises and more than 149 employees for the large scale."

Thus, for this study, the population is defined based on the following criteria:

1) The sample unit must fit into the aforementioned definition.

2) The SME has had a succession within the period 2000 to 2007.

3) A family member successor or an unrelated manager successor has been appointed to the top executive senior position (CEO/ Chairman).

The database managed by the National Chamber of Commerce in Sri Lanka used to distinguish FOBs from SMEs. For selecting sample units, the following procedure has been applied.

\subsection{Sample Selection Procedure}

To reach this sample framework, the research has implemented the following procedure:

1. Send the questionnaire to the entire database by post / email and ask the sample group to complete and return the attached questionnaire.

2. Request the sample group to answer section one, especially designed to recognise whether an SME is within the sample framework or not. Under section 1 of the questionnaire, the successor must answer questions to verify features of the business units that match the sample framework:

- Ownership of the entity

- Number of employees

- Whether they have had a BSP

- The time period when the BSP was completed

- Successor mode 
3. If they have selected the answers (below), then that SME is identified as a sample unit and asked to answer the remainder of the questionnaire.

- Majority of ownership belongs to owner-family

- Employees are in between 50-149

- We have done BSP within the period 2000 - 2007

- Our successor mode is family member successor (FMS) / unrelated manager successor (UMS)

Figure 1 shows the above mentioned sample selection procedure.

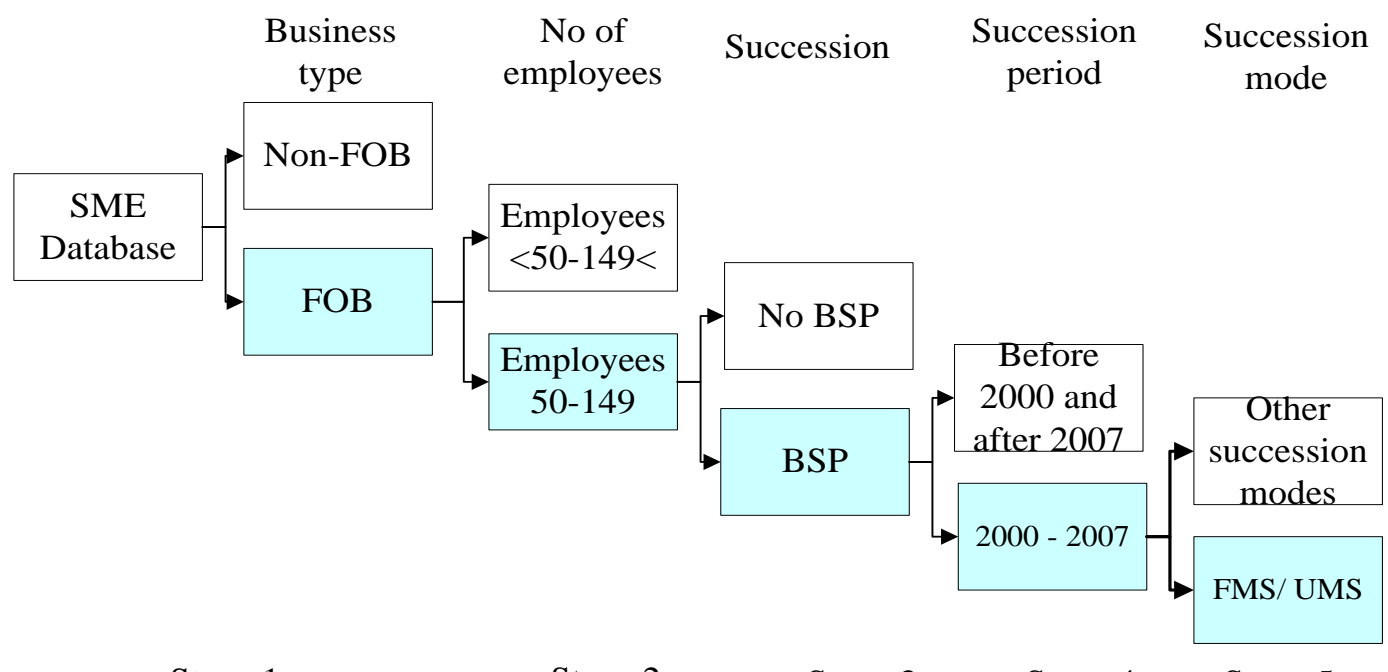

$\begin{array}{lllll}\text { Stage } 1 & \text { Stage } 2 & \text { Stage } 3 & \text { Stage } 4 & \text { Stage } 5\end{array}$

\section{Figure 1: Sorting procedure to identify sample units}

Source: Designed by the author

Under these circumstances, the research used a simple random sampling method by considering constraints faced during data collection.

\subsection{Sample Elements}

Targeted respondents included FOB successors: family member successors and unrelated manager successors that had been appointed within the period 2000 to 2007 in medium-sized FOBs. 


\subsection{Instrument and Questions}

A structured research questionnaire that has developed by combining with universal accepted scales and author developed scales.

This questionnaire was basically divided into three sections by considering the following objectives: Section 1was specially designed to verify which elements of the population should be subjects of the sample. Section 2 designed to collect demographic information about FOBs and the sample element; the successor. This section also helped collect data on pre and post business performance (objective 1). This section included the following demographic information related to the successor and FOB. In addition to the financial data, the study used Venter et al. (2005) "the perceived success of the succession process" scales for collecting business performance information subjectively (section 3). The original alpha values for this scale was 0.84 . Initial satisfaction with the succession process was measured through the scale developed by Sharma et al. (2003a). This instrument was constructed by 12 statements which were equally weighted. Every independent variable was also a construct calculated as an equally weighted average of the relevant indicators. The original alpha values for this scale was 0.93 . The questionnaire was originally developed in the English language, and then translated into Sinhala and the Tamil language. It was distributed in two formats: Sinhala and English format, or Tamil and English format, to increase the response ratio from the respondents.

\section{Data Collection Methods}

This study utilized postal and electronic mail surveys simultaneously as the data collation method due to the following reasons:

1) To obtain a higher level of response within a short period of time.

2) The population was scattered over the entire country.

3) There were difficulties identifying elements of the population

4) It gave a bigger opportunity to refuse without response (This research did not address exact sample units due to the unavailability of database who did their BSP within the period 2000 to 2007. Thus, it addressed the Managing Directors of SMEs in Sri Lanka and requested responses if they were suitable to fulfil the requirements 
of the sample framework. This approach can be used for the sample group to refuse without responding to the questionnaire).

The questionnaire was sent with a covering letter and return-paid envelope to ensure it was convenient for the respondents to submit their information. The first reminder was sent three weeks after the initial mailing and the second reminder was sent after six weeks. In addition, selected FOBs were personally visited to some selected FOBs in order to get a deeper understanding about their BSPs.

\section{Data Analysis and Interpretation}

This data analysis and interpretation stage consisted by fowling steps:

Compare business performance after succession and initial satisfaction of two succession modes (objective I)

\section{Initial satisfaction about the BSP}

To compare initial satisfaction with the BSP, two independent sample t-tests were applied.

$$
T=\left(X_{F M S}-X_{U M S}\right) /\left(S_{X F M S-X U M S}\right)
$$

$X_{F M S}=$ means of the FOBs run by family member successors

$X_{U M S}=$ means of the FOBs run by unrelated manager successors

$\left(S_{x F M S-x U M S}\right)$ - is a pooled or combined standard error, or difference between the means

\subsection{Compare Post-succession Business Performances}

In most of the studies, student " $\mathrm{t}$ " test, and ANOVA have been utilized to measure performance of the organizations, but the new trend is to compare performance through Difference-Indifferences (DD) analysis. This can particularly be seen with recent family business research when it compares family successor performance with non-family successor performance; or family firm with non-family firm performance (Bennedsen, Nielsen and Pe'rez-Gonza'lez 2006; Cucculelli and Micucci, 2008). Based on the suggestion given by Barber and Lyon (1996), Bennedsen et al. (2006), use non-parametric test statistics when analysing accounting based data due to the problem of outliers. By 
following the Bennedsen et al. (2006), this study also applied the Mann-Whitney test to compare post succession performance of these two successor modes.

$$
Y_{1}=\beta_{0}+\beta_{1} * T+\beta_{2 F s u c e s}+\beta_{3} *(T * \text { Fsuces })+e
$$

\section{Where:}

$\mathrm{Y} 1=$ the difference in performance around BSP

$\mathrm{T}=$ time dummy

Fsuces $=$ an indicator variable equal to one if the incoming successor is family member and zero if unrelated manager.

( $\mathrm{T}^{*}$ Fsuces $)=$ is the interaction of the time dummy and the successor dummy

\subsection{Reliability and Validity}

To increase validity and reliability, the author used a pilot survey to pre-test the questionnaire. According to Cooper and Schinder (2008), this type of pre-testing reduces the risk of exhausting the supply of respondents and increases the sensitivity of respondents to the purpose of the study. For the pilot survey, 10 successors were selected from the population, and the survey instrument was a structured questionnaire. Each successor took about 20 to 25 minutes to complete the questionnaire after the research objectives were explained. The author directly assisted the respondents to fill in the questionnaire by clarifying instructions and explanations. As a result of the pilot survey, a number of changes were made to improve the clarity of the questionnaire and to improve the construct validity of the questionnaire. This helped to increase the efficiency of the questionnaire and survey data.

Moreover, to test the internal consistency and reliability of the study, it used Cronbach's alpha. Prior to performing statistical analysis on the hypothesis, reliability and validity tests were conducted using SPSS 17.0 to confirm internal consistency. Table 2 reports that Cronbach's alpha values of the variables exceed the 0.7. The research employed the scales developed by Sharma et al. (2003a) and Venter et al. (2005) for the present study. Sharma (2003) and Venter et al (2005) have confirmed that the scales were reliable (Cronbach's alpha values were within the acceptable range). However, these 
scales were translated to Sinhala and Tamil languages. Therefore, again a reliability analysis was done and all independent and dependent variables were within the acceptable range.

Table 2: Reliability Analysis

\begin{tabular}{lcc}
\hline \multicolumn{1}{c}{ Construct } & Variable & Cronbach's Alpha \\
\hline Business performances & .821 \\
\hline Initial satisfaction with the business succession process & .721 \\
\hline
\end{tabular}

Source: Pilot survey, 2011

\subsection{Response Rate}

In total, 156 responses were received during the data collection period. The number of useable returns is $128(82 \%)$ and the number of non-useable returns is $28(18 \%)$. The 28 responses had to be rejected particularly from hypothesis testing, since they did not have several key questions entirely completed. The overall response rate (useable returns 128; total population 3,458 ) suitable for hypothesis testing is $3.7 \%$. The response rate on the web-based survey was less than that of the postal questionnaire. It is likely that companies apply a spam filter to e-mails from unknown sources, and secretaries usually check and filter incoming e-mails for the executive. This response was still a more than adequate response rate, given the number of parameters in the structural model to be estimated (Hair, Anderson, Tatham and Black, 1995). The 128 usable questionnaires were evenly split between two respondent groups: 86 questionnaires received from family member successors, and 42 received from unrelated manager successors. In addition to the statistical requirements of sample selection, this sample of the study can be matched with the study samples that have been used to evaluate post succession performance of FOBs and non-FOBs, therefore this sample size of the study is considered acceptable for this study (Cucculelli and Micucci, 2008). 


\section{Data Analysis and Discussion}

\subsection{Comparison of post succession performance}

\section{Initial satisfaction with the succession process}

(1) Initial satisfaction of the business succession process

Alternative hypothesis $\left(\mathbf{H}_{\mathbf{1 . a}}\right)$ : Initial satisfaction with the business succession process is significantly different with family member successors $\left(\mu_{S F M S}\right)$ to unrelated manager successors $\left(\mu_{S U M S}\right)$

$$
H_{1}: \mu_{S F M S} \neq \mu_{S U M S}
$$

A study compared the level of initial satisfaction of family member successors and unrelated manager successors. Family member successors levels of initial satisfaction (M $=2.63, \mathrm{SD}=0.65)$ expressed significant levels of difference with unrelated manager successors $(\mathrm{M}=3.00, \mathrm{SD}=0.41), \mathrm{t}(128)=3.939, \mathrm{p}=0.000$, and two-tailed $\mathrm{df}=117.01$.

According to the research findings, unrelated manager successors have a higher level of initial satisfaction than the family member successor.

Therefore, alternative hypothesis $\left(H_{1 . a}\right)$ is accepted. In other words, initial satisfaction with the business succession process between family member successors and unrelated successors is significantly different.

Table 3: Initial satisfaction with the business succession process

Type of business succession

\begin{tabular}{|c|c|c|c|c|}
\hline & All & $\begin{array}{c}\text { Family } \\
\text { member } \\
\text { successor }\end{array}$ & $\begin{array}{l}\text { Unrelated } \\
\text { manager } \\
\text { successor }\end{array}$ & Difference \\
\hline $\begin{array}{l}\text { Initial } \\
\text { Satisfaction }\end{array}$ & 2.77 & 2.63 & 3.00 & $0.27 *$ \\
\hline
\end{tabular}

* Denotes significance at the $5 \%$ level

Dependent variable: Initial satisfaction with the business succession process Source: Survey data 
The average satisfaction with the BSP is 2.77. Under this condition, it can be concluded that not all successors are satisfied with the BSP that was carried out. The stakeholders around the BSP should consider the BSP because if they highly satisfied with the business succession, it will positively affect the performance of the business.

\subsection{Comparison of post succession business performances}

Alternative hypothesis $\left(\mathbf{H}_{\mathbf{1 . b}}\right)$ : Post succession business performance of the two succession modes is significantly different. (Performance of the family member successor $\left(\mu_{F M S B P}\right)$ is significantly different to the performance of the unrelated manager $\left.\left(\mu_{U M S B P}\right)\right)$.

$$
H_{1}: \mu_{F M S B P} \neq \mu_{U M S B P}
$$

Table 4 presents the descriptive statistics of profitability measured by the ROA and ROS. The comparison of post succession performance between the two succession modes has become an extremely difficult issue to deal with. This became even worse in situations where social habits and inheritance norms strongly affect the successor selection in the transfer of business (Bertrand and Schoar, 2006) and the FOBs are pervasive in the economy. Therefore, a more detailed analysis was restricted to just the discussion of BSPs.

For the sub-samples of family member successor managed and unrelated manager successor managed FOBs, accounting data was used. The total sample of companies that experienced a BSP in the time interval of 2000 to 2007 and which had accounting data available for the three-year window before and after the transition was 128 firms.

Table 4 presents the descriptive statistics of profitability measured by the Average Returns on Assets (Avg. ROA) and Average Returns on Sales (Avg. ROS). Profitability data is the simple average for each group. Family successions are almost entirely from the first to second generation transfers, whereas only 14 out of 86 transfers are to the third generation or further. The group averages reported in Table. 4 have been calculated after including all 86 family successions.

Post succession performance shows a clear decline in profitability for both indicators in family member successor managed and unrelated manager successor managed 
companies: for the total sample, Avg. ROA decreases from 8.83 to 7.97, whereas Avg. ROS decreases from 7.72 to 6.76 . The decline appears to be larger for family member successor managed FOBs than for unrelated manager successor managed FOBs, and it is statistically significant for both indicators.

Family member successor managed FOBs experience rather similar decreases in the post succession performance for both Avg. ROA and Avg. ROS (-0.89 and -0.81 respectively shown in Table 4), which suggests a post succession turnaround significantly different from that observed in unrelated manager successor FOBs. By contrast, unrelated manager successor managed firms exhibit a considerable post succession decrease in the Avg. ROA (from 0.77 to 0.62 ), whereas there appears to be a smaller effect on ROS. In this case, even if the observed changes in profitability are statistically significant, it can be presumed this is due to the post succession process in these FOBs.

The estimated results, as reported in table 4 (panel A for Avg. ROA and panel 2 for Avg. ROS), shows that succession causes a reduction in profitability, both in family member successor managed and unrelated manager successor managed companies, which signals the existence of costs due to succession in both types of firms. There is only a minor difference in Avg. ROA rates between family member successors managed and unrelated manager successors managed FOBs, though the intensity of the impact is quite different when profitability is measured by the Avg. ROS. In these cases, family member successor managed firms clearly underperform compared with unrelated manager successor managed FOBs.

Therefore, an alternative hypothesis is accepted. In other words, there are statistically significant differences between the post succession performances of family member successors and post succession performances of unrelated successors. 
Table 4: Successions and changes in business performance

Type of business succession

\begin{tabular}{lcccc}
\hline & All & $\begin{array}{c}\text { Family } \\
\text { member } \\
\text { successor }\end{array}$ & $\begin{array}{c}\text { Unrelated } \\
\text { manager } \\
\text { successor }\end{array}$ & Difference \\
\hline Panel : Avg. ROA & & & & \\
\hline Before & 8.83 & 9.34 & 7.54 & $1.80^{*}$ \\
& $(.2665)$ & $(.3468)$ & $(.2296)$ & $(.5669)$ \\
& {$[128]$} & {$[86]$} & {$[42]$} & \\
\hline After & 7.97 & 8.45 & 6.77 & $1.68^{*}$ \\
& $(.2221)$ & $(.2778)$ & $(.2529)$ & $(.4670)$ \\
& {$[128]$} & {$[86]$} & {$[42]$} & \\
\hline Difference & $-0.85^{*}$ & $-0.89^{*}$ & $-0.77^{*}$ & $-0.12^{*}$ \\
& $(.3024)$ & $(.3777)$ & $(.3183)$ & $(.2836)$ \\
\hline Panel B : Avg. ROS & & & & \\
\hline Before & 7.72 & 7.97 & 7.09 & $0.88^{*}$ \\
& $(.1669)$ & $(.2102)$ & $(.2245)$ & $(.3076)$ \\
& {$[128]$} & {$[86]$} & {$[42]$} & \\
\hline After & 6.96 & 7.16 & 6.46 & $.70^{*}$ \\
& $(.1231)$ & $(.2063)$ & $(.2422)$ & $(.2784)$ \\
& {$[128]$} & {$[86]$} & {$[42]$} & \\
\hline Difference & $-0.75^{*}$ & $-0.81^{*}$ & $-0.62^{*}$ & $-0.19^{*}$ \\
& $(.2836)$ & $(.2422)$ & $(.2718)$ & $(.1890)$ \\
\hline
\end{tabular}

Note: unrelated manager successor show a decline in their performance, but less of a decline the family member successor.

A. Successors of FOB BSP are classified into two groups: family member successors whereby the entering successor is related by blood or law to the incumbent; and non-family manager successors who are not related.

B. Panel A reports the average ROA. Panel B reports the three-year average ROS before and also the three-year average after BSP. It also reports differences in these measures around the BSP and differences (differences-in-differences-DD) around the BSP. In all cases, the year of succession is neglected.

C. Standard errors are in parentheses and the numbers of observations are in square brackets. The sign $*$ denotes significance at the $5 \%$ level.

D. Dependent variables: Avg. ROA and Avg. ROS

Source: Survey Data 
Theoretically, family member successor performance must be higher than unrelated manager successor performance because family members have greater opportunities of receiving benefits from FOBs than outsider, non-relatives. Family members can also easily utilize knowledge developed by family members, and the level of trust between successor and other family members directly affects this knowledge sharing. In addition to these factors, family member successors should have a higher degree of commitment toward the FOB because the company represents their own personal prosperity.

However, the results of the study go completely contrary to the theoretical back up hypothesis, and there are several reasons for this. The first generation of business management is usually more business-oriented than the second and following generations. The first generation took higher risks when they founded the family business. They gave first priority to develop the business and later focused on satisfying the family. When the business transfers to the second generation though, this type of business focus cannot be expected. In addition to this, conflicts between family members and the unnecessary involvement of the incumbent are other major reasons why the results show stagnation and decline.

Another factor is that FOBs which have appointed family member successors to have better pre-succession performance the FOBs which have appointed unrelated manager successors. FOBs are generally more eager to transfer management outside the family when it has performed unsuccessfully or when there is no suitable family successor. This unrelated manager takeover of a poorly running FOB affects how family member successor managed post succession performance compares with unrelated manager successor managed companies.

According to research in Spain "firm performance does not influence the decision of that the next successor, because owners are highly concerned with long-term survival of the firm rather than with other relationships they have. They are quite professional and appoint whoever can lead the FOB into a successful future." However, in Sri Lanka, the findings are totally different. Sri Lankans give their foremost priority to handing over businesses to family members. If relatives refuse this appointment then the appointment goes to another alternative option. Regarding the ethics of business, this is acceptable 
because this is a family business and it should be transferred from one generation to another.

Again, unrelated manager successor businesses have recorded better performances the family member successor businesses during the period after the BSP. They have actually minimized the decline in performance more so the family member successors. This can happen due to a number of reasons. Unrelated manager successors have an established track record of performance. They have a number of years' experience within or outside the FOB and have received management positions due to their proven track history of competence, they therefore do not need a grooming period; but this situation does not exist with family member successors. They must rely on their existing competencies and skills and training takes a period of time.

In addition to lack of competence, there are several other reasons for this poor performance. There are tensions between family goals and FOB objectives, and in a very small sub-set, problems develop when choosing a successor therefore, that selection cannot be recognize appropriate one for the appointment. Sometime, successors cannot take a correct decision due to the "nepotism". It is a much more difficult task for the successor to make a decision to fire a family member due to misconduct or poor performance, In addition to that, the successor must work under a great deal of pressure because all family members have high expectations, and they are comparing them with the incumbent.

\subsection{Relationship between initial satisfaction and post succession business performance}

Pearson's correlation coefficient was applied to test the relationship between the successor's initial satisfaction with the business succession process and post succession business performance. Table 5 shows the result. According to this result, these variables have a statistically significant relationship. 
Table 5: Relationship between successor's initial satisfaction with the business succession process and post succession performances

\begin{tabular}{lccc}
\hline Initial satisfaction & Sll successors & $\begin{array}{c}\text { Family } \\
\text { member } \\
\text { successor }\end{array}$ & $\begin{array}{c}\text { Unrelated } \\
\text { manager } \\
\text { successor }\end{array}$ \\
\hline Pearson Correlation & $.564^{* *}$ & $.776^{* *}$ & $.361^{* *}$ \\
\hline Sig. (2-tailed) & .000 & .000 & .019 \\
\hline $\mathrm{N}$ & 128 & 86 & 42 \\
\hline
\end{tabular}

**. Correlation is significant at the 0.01 level (2-tailed).

Source: Survey Data

When the successor is satisfied with the BSP, it directly influences his post succession commitment to perform well for the business. It also affects the post succession performance and therefore the successor's satisfaction also highly influences factors of survival for the FOB. Therefore, the successor's satisfaction is the critical factor of the entire succession process.

\section{Research Conclusions and Recommendations}

When the incumbent is getting close to retirement, the FOB and the owner-family is in a dilemma about the new successor appointment, and success after the new appointment. If this process fails, that occurs just occasionally, it is the biggest loss in the entire life of the business entity. It is clearly not a regular incident in these generic types of businesses. Succession usually means one generation handing management to the next generation. Most managers and family members do not have any experience with business succession processes. On some occasions, just the incumbent has some understanding of what is going to take place, due to the fact that he was the successor in the last transition.

A successful changeover is extremely dependant on two foremost decisions. The first one is choosing the appropriate successor, and the second one is managing influential factors so as to maximise successor satisfaction because this directly affects post succession performance of the business unit, not only that, however the successor's 
willingness to work under the existing ethical climate and culture of the FOB is a crucial influence, because it has great influence on performance.

Under these circumstances, the author was in a conceptual puzzle: are successors satisfied with the business succession process? Do family member successor diminish organizational performance? Can unrelated manager successors perform better than the family member successors? What are the factors influencing successful business succession process, and so on. Finally, this motivated the author to conduct empirical study to investigate those questions.

In the first stage, the author conducted an exploratory study to recognise performance measurement indicators.. Based on these findings, the author developed hypothesis for the formal study. Medium-sized FOBs who have gone through a business succession process within 2000 - 2007 are the identified population for this study. A mail survey was conducted, some in-depth discussions were held with successors to collect data, and finally statistical analysis was used to test hypothesis and find answers. Based on these analyses, the study solves the conceptual puzzle.

According to aforesaid findings, successors are not satisfied with the business succession process. This is true of all the succession modes. Unrelated manager successors have higher satisfaction than the family member successors but no successors achieve more than the moderate level of satisfaction. This level achieved indicates "no dissatisfaction and no satisfaction" and this is dissatisfactory for the future of the FOB. If CEOs do not satisfy the way of appointing them, it badly affects the performance.

According to empirical findings from this study, successors have had a damaging influence on business performances, true for family member successors as well as unrelated manager successors. All successors recorded lower performances than the incumbent, which is a discouraging sign for the future existence of the FOB. The incumbent is the one who took the most risks to start the business, built the business over an extended period of time and thus he has greater experience and capacity than the successor. There are though, many opportunities to groom potential successors to the required business ability levels before the succession process. 
This study compares performances of family member successors with that of unrelated manager successors, based on both subjective and objective indicators in order to recognise the most successful successor under the highest level of family involvement. Unrelated manager successors recorded better performance than the family member successors in both perspectives. They have higher levels of satisfaction with the business succession process and better business performance.

According to performance, unrelated manager successors are most suitable to take over management from the incumbent, however it is not the most appropriate appointment when family members demand to be the successor. On one side, it will create a number of inter-family conflicts and it badly affects the day to day business activities. From another perspective, FOBs belong to the family and if they do not have an opportunity take the lead in their own company, they are unlikely to get this opportunity outside the company. It is far better to encourage that committed member to acquire the required competence and give them the chance to manage the company. However, when a FOB does not have an available family member, an unrelated manager successor is the best alternative to consider. Not only that, if owners require running the FOB under professional management, then this is a good alternative.

According to study findings, the successor's satisfaction with the business succession process directly influences business performance. Simultaneously, the level of commitment, family harmony, and the relationship between incumbent and successor all directly influence both initial satisfaction with the business succession process and business performance.

\section{Limitations of the Research}

This is the first study that empirically evaluates an integrated model of stakeholder related factors impacting on the business succession process in medium-sized FOBs. Using quite a large sample, this addresses issues to obtain a better understanding of the succession process. This approach deviates from the current approach in this field: anecdotal evidence, case studies, and small-scale descriptive studies. This study attempts to significantly contribute to the body of knowledge of business succession processes in medium-sized FOBs however there are still further areas needed to investigate. Due to the 
lack of a database for Sri Lanka, the number of sample units is limited to 126 . Therefore, study evaluations are limited to multiple regressions.

\section{Bibliography}

ALESTALO, A. Gender effect, family characteristics and firm performance on succession decisions - Evidence from Finnish, family firms, Finance Master's thesis Annika Alestalo, Helsinki school of Economics,[online], 2010, [quot. 12 June 2011]. Available on World Wide Web:

http://hsepubl.lib.hse.fi/EN/ethesis/pdf/12233/hse ethesis_12 233.pdf.

\section{AMERICAN FAMILY BUSINESS SURVEY. The Arthur Andersen/Mass Mutual} American family business survey, [online], 1997, [quot. 10 February 2010]. Available on World Wide Web: http://www. arthuranderse .com/CFB.97surv.asp.

BARBER, B. M., LYON J. D. Detecting abnormal operating performance: the empirical power and specification of test statistics, J. of Financial Economics, 1996, vol. 41, p. 359-399, ISSN: 0304-405X.

BECKHARD, R., DYER, W. G., JR. SMR Forum: Managing Change in the Family Firm: Issues and Strategies, Sloan Management Review, 1983, vol. 24, no. 3, p. 59-65, ISSN: 15329194.

BENNEDSEN, M., NIELSEN, K. M., PE`REZ-GONZA`LEZ, F., WOLFENZON, D. Inside the family firm: the role of families in succession decisions and performance. The Quarterly J. of Economics, 2007, vol. 122, iss. 2, p. 647-691.

BERTRAND, M., SCHOAR, A. The role of family in family firms, J. of Economic Perspectives, 2006 spring, vol. 20, no. 2, p. 73-96, ISSN: 08953309.

BJUGGREN, P., SUND, L. Strategic Decision Making in Intergenerational Successions of Small and Medium-Size Family owned Businesses. J. of Family Business Review, 2001, vol. 14, iss. 1, p. 11-24, ISSN: 0266-2426.

BOEKER, W., GOODSTEIN, J. Performance and Successor Choice: The Moderating Effects of Governance and Ownership. The Academy of Management J., 1993, iss. 1, p. 172-186, ISSN: 1963-2006. 
BROCKHAUS, R. H. Family Business Succession: Suggestions for Future Research. $J$. of Family Business Review, 2004, vol. 54, iss. 4, p. 105-114, ISSN: 0894-4865.

CABRAAL, N. A. Medium-size SME's Sri Lanka. The symposium of Making SME finance Profitable [online], 2007, [quot. 11 March 2011]. Available at WWW: <http://www.ifc.org/ifcext/southasia.nsf/Attach mentsByTitle/LargerSMEs/\$FILE/Larger+SMEs+-slbdC+NivardCabraal .pdf>.

CABRERA-SUAREZ, K., DE SAA-PEREZ, E, GARCIA-ALMEIDA, D. The succession process from a resource and knowledge-based view of the family firm, J. of Family Business Review, 2001, vol. 114, no. 1, p. 37-47, ISSN: 08944865 .

CAMPBELL, J. P. On the nature of organizational effectiveness. In P.S. Goodman and J.M. Pennings [Eds.], New perspectives on organizational effectiveness, San Francisco: Jossey-Bass. 1977, p.13-55.

CHITTOOR, R., DAS, R. Professionalization of management and Succession Performance - A vital Linkage Succession Performance, J. of Family Business Review, March 2007, vol. 20 no.

CHRISMAN, J. J., CHUA, J. H., SHARMA, P. Trends and Directions in the Development of a Strategic Management Theory of the Family Firm, $J$. Entrepreneurship Theory and Practice, 2005, vol. 29, iss. 5, p. 555-576, ISSN: 15406520 .

CHUNG, H. M., LIU, Y. S. The Business of Taiwan's Succession in Family Business. [Online]. 2007, [quot. 27 December 2010]. Available on World Wide Web: 〈http://www.isb.edu/FamilyBusinessConfer ence pdf >.

COMMISSION E. Markets for Business Transfers Fostering Transparent Marketplaces for the Transfer of Businesses in Europe. European Commission Enterprise and Industry Directorate- General: Brussels [online], 2006. [quot. 27 December 2010]. Available on World Wide Web: http://ec.europa.eu/enterprise/policies/sme/files/support_me as ures/tran sfer_business/transfer_markets_en.pdf.

COOPER, D., SCHINDLER, P. Business Research Methods, 10th Ed. McGraw-Hill Higher Education. 2008, p. 768, ISBN: 10 0-07-340175-7. 
COORAY, M. N. R. Walk through Cleaner Production Assessment in SME's - A Case Study from Sri Lanka, Small to Medium Enterprise, [online], 2003, [quot 25 March 2011]. Available on World Wide Web: ttp://www.sdsap.org/ data/ Cooray_W05.pdf.

COORAY, M. N. R., DE SILVA, K R. Facilitating the development of SMEs of Sri Lanka through sustainable consumption and production. [Online]. 2007, [quot. 2011-01-22]. Available on World Wide Web:<http://www.ncpcsrilanka.org/Roudtable\%20Web/Papers/T25.pdf >.

CUCCULELLI, M., MICUCCI, G. Family succession and firm performance: evidence from Italian family firms. Temi di discussion [Working papers], [online], 2008 June, [quot. 22 January 2011] Available on World Wide Web: http://www.bancaditalia.it/pubblicazioni /econo/temi di/td08/td680_08/td680/en_tema_680.pdf.

DAILY, C. M., DOLLINGER, M. J. An empirical examination of ownership structure in family and professionally managed firms, J. of Family Business Review, 1992, vol. 5, iss. 2, p. 117-136, ISSN: 0894-4865.

DASANAYAKA, S. SMEs in globalised world: A brief note on basic profiles of Pakistan's SMEs and possible research directions, Business Review J., 2008, vol. 3, no.3, p. 69-78, ISSN: 1990-6587.

DAVIS, J. H., SCHOORMAN, F. D., DONALDSON, L. Toward a Stewardship Theory of Management. J. of Academy of Management Review, 1997, vol. 22, iss. 1, p. 20, ISSN: 03637425.

DAVIS, P. S. HARVESTON, P. D. The Influence of Family on the Family Business Succession Process: A Multi-Generational Perspective. J. of Family Business Review. 1998, vol. 22, ISSN: 0894-4865.

DE ALWIS, A. C. Business succession in medium size family companies, In. Proceedings of the 17th International Business Information Management Association, Milan, Italy, Nov 2011, ISBN: 978 0-9821489-6-9.

DONALDSON, T, PRESTON, L. E. The Stakeholder Theory of Corporation: Concepts, Evidence and Implication, Academy of Management Review, 1995, vol. 20, iss. 1, p. 65-91, ISSN: 03637425. 
DONNELLEY, ROBERT G. The Family Business, Harvard Business Review, 1964, vol. XLII, p. 93-105, ISSN: 00178012.

DYCK, B., MAUWS, M., STARKE, F. A., MISCHKE, G. A. Passing the baton: The importance of sequence, timing, technique and communication in executive succession, J. of Business Venturing, 2002, vol. 17, iss. 2, p. 143-162, ISSN: 1204474818 .

DYER, W. G. JR. Cultural change in family firms: Anticipating and managing business and family transitions, San Francisco: Jossey-Bass. A, E, 1986, ISBN: 978-0470-62200-1.

ETZIONI, A. Modern Organizations (Prentice-Hall Englewood Cliffs, N.J), 1964, p. 120

FILE, K. M., PRINCE, R. A., RANKIN, M. J. Organizational buying behavior of the family firm. J. of Family Business Review, 1994, vol. 8, no. 1, p. 29-40, ISSN: 0894-4865.

GOLDBERG, S. Effective successors in family owned businesses: Significant elements. J. of Family Business Review, 1996, vol. 9, no. 2, p. 185-197, ISSN: 0894-4865.

GONZÁLEZ, P. Inherited Control and Firm Performance, American Economic Review, December 2006, vol. 96, no. 5, p. 1559-1588.

HAIR, J. F., ANDERSON, R. E., TATHAM, R. L., LACK, W. C. Multivariate Data Analysis: with Readings, Englewood Cliffs, New Jersey: [online], 1995 Prentice Hall. [quot. 12 March 2011]. Available on World Wide Web: http://www.mediafire.com/?mkrzmjmmonn.

HANDLER, W. C. Managing the family firm succession process: The next generation family member's expedience. Doctoral dissertation School of Management, Boston University [online]. 1989b, [quot. 12 March 2011] Available on World Wide Web:,http://www.uk.sagep ub.com/chaston/20chapters\%20112/Chapter\%2011\%20-\%2014.

HANDLER, W. C. Methodological issues and considerations in studying family businesses. J. of Family Business Review, 1989a, vol. 26, iss. 2, p. 49-56, ISSN: $0894-4865$. 
HANDLER, W. C. Succession experience of the next generation, J. of Family Business Review, 1992, vol. 5, no.3, p.283-307, ISSN: 0894-4865.

HANDLER, W. C. Succession in family firms: A mutual role adjustment between entrepreneur and next-generation family members. J. of Entrepreneurship Theory and Practice, 1990, vol. 15, iss. 1, p. 37-51, ISSN: 10422587.

HANDLER, W. C., Succession in family businesses: A review of the research. J. of Family Business Review, 1994, vol. 7, no. 2, p. 133-157 ISSN: 0894-4865

HARVEY, M., EVANS, R. Strategic windows in the entrepreneurial process, J. of Business Venturing, 1995, vol. 10, iss. 5, p. 331-347, ISSN; 0883-9026.

JARVIS, R., KITCHING, J., CURRAN, J., LIGHTFOOT, G. The Financial Management of Small Firms: An Alternative Perspective, ACCA Research Report, 1996, no. 49, ISBN: 1898291640.

KETS DE VRIES, M. F. R. The dynamics of family controlled firms: The good and the bad news. J. of Organizational Dynamics, [online], 1993, [quot. 12 March 2011], Available on World Wide Web: http://gsapp web. rutgers.edu/cstudents/readings/Summer/Ballet_FamilySystems/ketsdevries_dyna mics.pdf.

KING, S., Organizational Performance and Conceptual Capability: The Relationship between Organizational Performance and Successors' Capability in a Family owned Firm. J. of Family Business Review, 2003, vol. 16, no. 3, p. 173-183, ISSN : $0894-4865$.

KOTEY, B. Goals, management practices, and performance of family SMEs.

International J. of Entrepreneurial Behavior and Research, 2004, vol. 11, Iss. 1, p. 3-24, ISSN: 1355-2554.

LANSBERG, I. Succeeding generations: Realizing the dreams of families in business. 1st ed., Harvard Business School Press, Boston: 1999. p. 379, ISBN: 0087584742-0127.

LAUTERBACH, B., VU J., WEISBERG, J. Internal vs. External Successions and Their Effect on Firm Performance, J. of Human Relations, 1999, vol. 52, no. 12, p. 1485-1504, ISSN:1573-9716. 
LIN, S., HU, P. Member of the Family or Professional Management? The choice of a CEO and Its Impact on Performance, J. of Corporate Governance: An International Review, 2007, iss 15, no 6, p.1348-1362, ISSN: 0964-8410.

MALHOTRA, H. B. Family Businesses and the Global Economy. The Epoch Times [online]. 2010, [quot. 18 December, 2010]. Available on World Wide Web:http://www.theepochtimes.com/n2/content/view/35702.

MANDL, I. Overview of Family Business Relevant Issues Contract No. 30-CE0164021/00-51, Final Report - Mandl 2008, [online], 2008, [quot. 18 December 2010] Available on World Wide Web: http://eceuropa.eu/ enterprise/policies/sme/files/craft/familybusiness/doc/familybusinessstudyn.pdfp .175 .

MEIJAARD, J. L., UHLANER, R., FLÖREN, B., DIEPHUIS, B., SANDERS, The relationship between successor and planning characteristics and the success of business transfer in Dutch SMEs, SCALES-paper N20050, [online], 2005, [quot. 25 March 2011] Available on World Wide Web: http://www.entrepreneurshipsme.eu/pdf-ez/N20 0505.pdf.

MILLER, D., STEIER, L., LE BRETON-MINER, I. Lost in time: Intergenerational succession, change and failure in family. J. of Business Venturing, 2003, vol. 18, iss. 4, p. 513-531, ISSN: 0883-9026.

MORCK, R., YEUNG, B., Family Control and Rent-Seeking Society. J. of Entrepreneurship Theory and Practice. 2004, iss. 38, no. 1, p. 79-92, ISSN: 1540- 6520 .

MORRIS, M. H., WILliAMS, R. O., ALLEN, J. A., AVILA, R. A. Correlates of success in family business transitions, J. of Business Venturing, 1997, iss. 12, no. 5, p. 385-401, ISSN: 0833-9026.

MUSTAKALLIO, M.A. Contractual and relational governance in family firms: Effects on strategic decision-making quality and firm performance, Dissertation for the degree of Doctor of Science in Helsinki University of Technology, [online], 2002, [quot.2 February 2011] Available on World Wide Web: http://lib.tkk.fi/Diss/2002/isbn9512263335/isbn951226333 5.pdf. 
NELTON, S. Hiring an outsider as a top executive. Business Publications, Nationas business [online]. Feb 1997, [quot.2 February 2011]. Available on World Wide Web: <http://findarticles.com/p/articles/mi_m1154/is_n2_v85/ai_19084105/>.

O'HARE, W. T., Centuries of Success: Lessons from the World's Most Enduring Family Businesses. 1ed, U.S.: Adams Media, F + W Publications, 2003, p. 323, ISBN: 1-58062-937-7.

PITCHER, P., CHREIM, S., KISFALVI, V. CEO Succession research: Methodological bridges over troubled waters. Strategic Management J., 2000, vol. 21, iss. 4, p.625-648, ISSN: 0143-2095.

PYROMALIS, V. D., ROGDAKI, M.E. An integrated framework for testing the success of the family Business Succession process according to gender specificity, [online]. 2004, [quot. 2010-11-20]. Available on World Wide Web:<http://www.sbaer.uca.edu/Research/al.

RIDING, A. Estimating Informal Investment in Canada. Report prepared by Equinox Management Consultants as part of the SME Financing Data Initiative [online], 2005, [quot. 25 March 2011]. Available on World Wide Web: http://www.smefdi.gc.ca/eic/site/sme_fdi-prf_pme.nsf/vwapj InformalInvestment_Eng.pdf/\$FILE/EstimatingInformalInvestment_Eng.pdf.

SEASHORE, S. E., YUCHTMAN, E. Factorial analysis of organizational performance. J. of Administrative Science Quarterly, 1967, vol. 12, p.377-395, ISSN: 0018392 .

SHANKER, M. C., ASTRACHAN, J. H. Myths and realities: Family businesses' contribution to the US Economy - A framework for assessing family business statistics. J. of Family Business Review, 1996, vol. 9, no. 2, p.107 -123, ISSN: 0894- 4485 .

SHARMA, P., CHRISMAN, J. J., CHUA, J. H. Predictors of satisfaction with the succession process in family firms, J. of Business Venturing, 2003, vol. 18, iss. 5, ISSN: ISSN: 0883-9026.

SHARMA, P. Determinants of the satisfaction of the primary stakeholders with the succession process in family firms [online], 1997, University of Calgary, Canada. [quot. 25 April 2011]. Available on World Wide Web: http://www.ucalgary.ca/files/haskaynefaculty/qualitysuccession.pdf. 
SHARMA, P. Stakeholder Mapping Technique: Toward the Development of a family firm typology. J. of Academy of Managements 2002 annual conference in Denver [online], 2003, [quot. 28 January 2011]. Available on World Wide Web: <http://www.wlu.ca/documents/842/2003-01-MOB. pdf>.

SHARMA, P., CHRISMAN, J. J., CHUA, J. H. A review and annotated bibliography of family business studies, 1996, Kluwer Academic Publishers: Boston, MA.ISBN: 9780792397830.

SHARMA, P., CHRISMAN, J. J., CHUA, J. H. Strategic management of the family business: Past research and future challenges. J. of Family Business Review, 1997, vol. 10, iss, 1, p.1-53, ISSN: 08944485.

SHARMA, P., CHRISMAN, J. J., PABLO, A. L., CHUA, J. H. Determinants of initial satisfaction business succession process in Family Firms: A Conceptual Model. J. of Entrepreneurship Theory and Practice, 2001, vol. 26, no.2, p. 17-35, ISSN: 1368-265X.

SHARMA, P., IRVING, P.G. Four Bases of Family Business Successor Commitment: Antecedents and Consequences. Entrepreneurship, J. of Theory and Practice, 2005, vol. 29, no.1, p. 13- 33, ISSN: 1540-6520.

SMITH, F., AMOAKO-ADU, B. Management succession and financial performance of family controlled firms, J. of Corporate Finance, 1999, vol. 5, iss. 4, p. 341368, ISSN: 09291199.

SUMANASENA, K-Country Paper Sri Lanka. [online] N,D, Sri Lanka Chamber of Small Industries, [quot. 18 December 2010]. Available on World Wide Web:<http://www.sphconsultants.com/icsi/anka.pdf >.

TAGIURI, R., DAVIS, J.A., On the Goals of Successful Family Companies, J. of Family Business Review, March 1992, vol. 5, no.1, p. 43-62, ISSN: 0894-4865.

VENTER E, BOSHOFF, C, MAAS, G. Succession in family businesses in South Africa: a comparative study of owner-managers and successors, [online], 2005, [quot. 2011-04-08]. Available on World Wide Web: <http://sbaer.ua.edu/research/icsb/2004/paper7.pdf. 
WANG, Y., WATKINS, D., HARRIS, N., SPICER, K. The relationship between succession issues and business performance: Evidence from UK family SMEs, International J. of Entrepreneurial Behaviour and Research, 2004, vol. 10, no.1/2, p.59-84, ISSN: 1355- 2554.

WARD, J. L. Keeping the family business healthy: How to plan for continuing growth, profitability, and family leadership, San Francisco: Jossey-Bass. A, E, 1987, p. 255, ISBN: 1-55542-026-5.

WORTMAN, JR., M. S., Theoretical foundations for family owned businesses: A conceptual and research based paradigm. J. of Family Business Review 1994, vol. 7, no.1, p.3-27. ISSN: 0894-4865.

ZAHRA, S. A. Predictors and financial outcomes of corporate entrepreneurship: An exploratory study, J. of Business Venturing, [online], 1991. [quot. 25 March 2011]. Available on World Wide Web:

http://www.sciencedirect.com/science/article/pii/088390269190019A

ZHANG, J., MA, H. Adoption of professional management in Chinese family business: A multilevel analysis of impetuses and impediments. Asia Pacific J. of Management [online]. 2009, [quot 25 March 2011]. Available on World Wide Web: <http://www.springer link.com/ content/104121540561372j/fulltext.pdf>. 